\title{
Women's issue in the prose of the 19th century in the context of the educational process
}

\section{A questão da mulher na prosa do século 19 no contexto do processo educacional}

\section{La cuestión de la mujer en la prosa del siglo 19 en el contexto del proceso educativo}

Inna Lipnytska ${ }^{1}$ iD, Iryna Savchenko ${ }^{1}$ iD, Inna Halak ${ }^{1}$ iD, Iryna Hryhorenko ${ }^{1}$ iD, Tetiana Bykova ${ }^{1}$ iD

${ }^{1}$ Department of Ukrainian Literature, National Pedagogical Dragomanov University, Kyiv, Ukraine.

Corresponding author:

Inna Lipnytska

Email: linich_in@ukr.net

How to cite: Lipnytska, I., Savchenko, I., Halak, I., Hryhorenko, I., \& Bykova, T. (2021). Women's issue in the prose of the 19th century in the context of the educational process. Revista Tempos e Espaços em Educação, 14(33), e16402. http://dx.doi.org/10.20952/revtee.v14i33.16402

\section{ABSTRACT}

The purpose of the article is to study the sources and pedagogical interpretation of the "women's question". The subject of the research is the "women's question" and its artistic realization in the novels of Marko Vovchok. The analysis of the problem was carried out by integrating the traditional methods of Russian comparative historical literary criticism with new approaches to world literary criticism - gender, sociocultural, postcolonial, and feminist. As a result of the study, we came to the conclusion that the pedagogical views on the "women's issue" in the writer were formed and developed under the influence of communication with the Ukrainian and European intelligentsia of the 19th century. The progressive part of the intelligentsia of the second half of the XIX - early XX century advocated a change in the social status of women. Representatives of public and pedagogical opinion believed that a woman can not only be a mother, wife, housewife, she is capable of self-realization in other areas of society, for which she needs a decent education. The journalistic work on this problem of women with a possible comparative characterization of the regions of some European countries, which in the period under study were part of the AustroHungarian empires, deserves further study.

Keywords: Education. Historical analysis. Pedagogical essence. Prose. Women's question. 


\section{RESUMO}

O objetivo do artigo é estudar as fontes e a interpretação pedagógica da "questão das mulheres". O tema da pesquisa é a "questão das mulheres" e sua realização artística nos romances de Marko Vovchok. A análise do problema foi realizada integrando os métodos tradicionais da crítica literária histórica comparativa russa com novas abordagens da crítica literária mundial - gênero, sociocultural, pós-colonial e feminista. Como resultado do estudo, chegamos à conclusão de que as visões pedagógicas sobre a "questão das mulheres" na escritora foram formadas e desenvolvidas sob a influência da comunicação com os intelectuais ucranianos e europeus do século XIX. A parte progressista da intelectualidade da segunda metade do século XIX - início do século XX preconizava uma mudança no status social das mulheres. Representantes da opinião pública e pedagógica acreditam que uma mulher não só pode ser mãe, esposa, dona de casa, mas capaz de se realizar em outras áreas da sociedade, para as quais necessita de uma educação digna. O trabalho jornalístico sobre este problema das mulheres com uma possível caracterização comparativa das regiões de alguns países europeus, que no período em estudo faziam parte dos impérios austro-húngaros, merece um estudo mais aprofundado.

Palavras-chave: Análise histórica. Educação. Essência pedagógica. Prosa. Questão feminina.

\section{RESUMEN}

El propósito del artículo es estudiar las fuentes y la interpretación pedagógica de la "cuestión de las mujeres". El tema de la investigación es la "cuestión de las mujeres" y su realización artística en las novelas de Marko Vovchok. El análisis del problema se llevó a cabo integrando los métodos tradicionales de la crítica literaria histórica comparada rusa con nuevos enfoques de la crítica literaria mundial: de género, sociocultural, poscolonial y feminista. Como resultado del estudio, llegamos a la conclusión de que las opiniones pedagógicas sobre el "tema de la mujer" en el escritor se formaron y desarrollaron bajo la influencia de la comunicación con la intelectualidad ucraniana y europea del siglo XIX. La parte progresista de la intelectualidad de la segunda mitad del siglo XIX y principios del siglo XX propugnó un cambio en el estatus social de la mujer. Los representantes de la opinión pública y pedagógica creían que una mujer no solo puede ser madre, esposa, ama de casa, es capaz de autorrealizarse en otras áreas de la sociedad, para lo cual necesita una educación digna. El trabajo periodístico sobre este problema de la mujer con una posible caracterización comparativa de las regiones de algunos países europeos, que en el período de estudio formaban parte de los imperios austrohúngaros, merece un estudio más detenido.

Palabras clave: Análisis histórico. Cuestión de mujeres. Educación. Esencia pedagógica. Prosa.

\section{INTRODUCTION}

A characteristic feature of domestic and foreign scientific research of the XXI century in the field of philology is the appeal to the literary text as an organic whole. The modern anthropological approach is aimed at finding the means and conditions for the formation of man as the creator of his individuality, which allows researchers to focus on thinking, feelings, self-awareness and worldview of the subject. At the stage of reforming the education sector, there is a need to ensure the implementation of interpretive competence in students as a component of professional training of future teachers. It is literary education that creates the opportunity to form such a person who is able to easily extract, process information obtained from various sources, use it for their own individual development. In real life, the student becomes competitive and successful with a high speech culture and active speech activity. Education with the artistic word promotes the appearance of a lively response to various life events, changes the attitude to things, restructures the subjective worldview. While reading the works, the student depicts a certain picture, a specific situation, an image, lives the described events. Moral norms and rules in works of art acquire a living meaning, become accessible and understandable and are easily accepted as the only correct course 
of action. Therefore, the literary image of the teacher becomes a model, provides the transition of humanistic and value orientations in the inner heritage of the individual.

The concept of the human image has been and remains central in women's fiction. The tendency to portray the individual in his own development has led to the formation of an inseparable link between literature and pedagogy. The image of the teacher, formed today in the collective consciousness, has its own history of development and formation. There is a concept of stereotype, which is based on the expected characteristics of anyone, including teachers. These include: high educational level, culture of speech and communication skills, compliance with status and social role, rigor of appearance, accuracy, discipline. The creation of the image of the "teacher" in society is influenced by world fiction. In the twentieth century, the idea of the concept of "teacher" had an ideological color. The depicted artistic image of the teacher was distinguished only by positive character traits, was endowed with hyperbolized qualities, was always set as an example. In the XXI century, the basic requirements for teacher activity are changing and are based on a comprehensive approach to education. The realization of the integrity of the new education is manifested in the performance of its main function - the formation of a comprehensively developed, harmonious personality, ensuring individual development, professional competencies. Pedagogical activity is a mandatory interaction, "communication between teacher and students, in the process of which their business and interpersonal relationships develop on the basis of cooperation, mutual trust, spirituality".

A special role in shaping the modern image of the "teacher" is played by literature, and in modern conditions by the mass media. They not only inform, but also through the presentation of certain patterns of behavior of the heroes of books, movies, TV shows create in the collective consciousness of society the idea of the bearer of the "female image". There are various kinds of professional stereotypes, stereotypes of thinking, behavior and actions in society. There is a certain "teacher" manner of behavior, which is enshrined in the "image of the teacher." The scientific literature, in particular, psychological and pedagogical, reflects the professionally necessary qualities of a teacher. Fiction, journalism and mass sources transfer the professional to various everyday situations, emphasizing the hyberbolization of professional qualities. Thus, it is works of art that allow, on the one hand, to reflect social ideas about the teacher, and on the other - to influence the formation of "image" in society. Many artists of the artistic word in different periods of literary history described the system of education, reflected the state of development of education, expressed their pedagogical views, which led to the creation of a special pedagogical discourse that allows to study the evolution of Ukrainian pedagogy.

At the present stage, there is no consensus on the time of the emergence of the so-called "women's issue" in the Russian Empire. Most modern domestic and foreign historians are inclined to believe that as an object of public attention it appeared in the mid-nineteenth century. - after the Crimean War and the beginning of the era of Great Reforms, although there are isolated attempts to prove the existence of the struggle for the emancipation of women at earlier stages, in the second half of the eighteenth - early nineteenth century. Indeed, the ideas of improving the family and social status of women in the Russian Empire appeared long before the formation of the liberal movement, but for a long time they were spread only in a narrow circle of male intellectual elite and had little response from women. The "women's question" became a socially important problem in the 1860 's, when the ideal of a free personality, which became extremely popular among the Russian intelligentsia, began to spread to women as well. In the 1860s, during the formulation and formulation of the "women's question," its main content was women's rights to education and work. Later, the understanding of "women's rights" significantly expanded at the turn of the nineteenth - early twentieth century. included property rights and the right to divorce, provided for the improvement of the situation in the family, the fight against prostitution and double standards in relation to sex, and others. At the same time, the "women's issue" has acquired an 
anthropological dimension, which manifested itself in a comprehensive discussion on the individual talent and special destiny of women. The "ideological" women's magazines played a role in the initiation and course of this discussion, but to date they have been considered only in fragments.

The work of the writer and philosopher Mark Vovchka is synchronized with the activation of the European women's movement in the mid-19th century. All the multifaceted pedagogical and artistic activities of the writer are the refutation of the bias towards the role and place of women in society inherent in the traditional mental consciousness, the destruction of the canons of gender roles, the denial of patriarchal views on the meaning of women's literature with its focus exclusively on the female readership.

With her works, Marko Vovchok entered the world emancipatory movement for the protection of the civil, economic and social rights of women. The problems of the "women's issue", women's identity in the Russian-language prose of the writer - a new level of anti-colonial (antiserfdom) discourse of the artist's early work, which undermined the foundations of the "spiritual empire", was based on the patriarchal institutions of the state.

Already in the first stories of the writer, the leading theme of her work is actualized - the fate of a woman and women's competition for the right to be herself, opposition to the colonial system of values, and, consequently, the formation of her own.

Early short prose, the novellas "Institute", "Three Fates" captured readers (even despite the negative reviews of critics, in particular F. Dostoevsky) with a special perspective of the reflection of the spiritual world and the social role of women, in her works there is often a victim of not only social, but and patriarchal traditions of society. At the same time, for the first time in literature, important and sensitive issues of a woman's social status, her desire for a free choice of life path, a desire for self-realization, spiritual searches, and vigorous activity, were also declared by the woman herself, frankly and sharply. The philosopher writer emphasizes the basic contradictions of the totalitarian system, which not only hinder the realization of a woman's dreams of happiness, which she understands as the harmony of personal and social, but often become the cause of her suffering.

Marko Vovchok "quite openly promotes the ideas of female emancipation, notes that marriage is not indispensable as the only acceptable status for a woman." Her work is permeated with the motives of a new, active, intelligent, self-sufficient woman. At the same time, if the Ukrainian-language works of Marko Vovchok are systematically present in the studies of national literary criticism, then the Russian-language creativity still requires deep scientific reading and adequate understanding.

The purpose of the paper is to study the sources and artistic interpretation of the "women's issue».

\section{METHODOLOGY}

The analysis of the problem was carried out by integrating the traditional methods of Russian comparative historical literary criticism with the new approaches of the world science of philosophy and literature - gender, sociocultural, postcolonial, and feminist.

\section{RESULTS AND DISCUSSION}

In contrast to early work, the issue of the emancipation of women in the prose of Mark Vovchk of the 60-80s. XIX century. acquires special relevance. Several factors contributed to this. Firstly, this is the personal character and special psychospiritual world of the writer, her strongwilled and psychological qualities, ability to resist adverse circumstances, life activism, optimism, persistence in defending her own convictions, vividly illustrates the secret marriage of young Maria Vilinskaya with Afanasy Markovich, a Ukrainian intellectual, "Unreliable" citizen, family life with whom promised neither prosperity nor peace. The choice of a life partner, made contrary to the 
traditions of the Russian patriarchal society, emphasizes the rebellious nature (later her heroines embody precisely these protest moods and love of freedom, features that were not characteristic of female images for the traditional literature of this period). The ability to withstand life's difficulties and at the same time the persistent desire to take her place in society, tailored according to masculine patterns, now prompts Maria Markovich to search for opportunities for selfrealization.

No less important was the fact that the writer actively traveled: in the $60 \mathrm{~s}$ she traveled almost all over Europe, stopping in cities - centers of Western culture (Berlin, London, Dresden, Heidelberg, Paris, Rome, Naples, etc.), where already from the end of the XVIII century. the idea of a woman's entry into civil rights was legalized in the public consciousness, including in Herzen's magazines "Kolokol" and "Polar Star", which the writer was fond of. Women's emancipation in the second half of the 19th century. realized in European countries not so much in the declarations of the independent behavior of women, as in the need for free labor, scientific, social activity. The active part of women fought for participation in various spheres of life, until then inaccessible to her, and most importantly, they sought to ensure that these achievements were accepted by society as equal to those of men (Ageeva, 2002).

France, filled with ideas of personal freedom, occupies a special place on the map of her travels. The role of a catalyst in the interest in women's problems was obviously played by Georges Sand, who in her novels destroyed the Christian mythologem of the sanctity of marriage. The ideas of the author of "Jacques" Marko Vovchok will embody in his life: the divorce from A. Markovich will take place according to the model of the novel of a French writer: a man will withdraw himself from her life, giving his wife complete freedom of action (Ageeva, 2019).

At the same time, Marko Vovchok expanded the range of emancipatory and pedagogical problems. Her works convince that their author has studied the history of the women's issue deeply enough, in particular, the program of actions of the writer herself and some of her heroines will overlap with the "Declaration of the Rights of Women and Citizens" by Maria Gouge (Aubrey), the leading slogan of which is given in the later works of Mark Vovchok " a woman is born to be free and in the first place is equal to a man "and with the ideas of self-realization of a woman by the English leader of the women's movement G. Taylor-Mill and her husband J. S. Mill. To defend the rights of women, Marco Vovchok will approach as a real lawyer: in Paris, she studies languages, "how much she reads" (A. Markovich), including political treatises, listens to a course of Thus, not only the problem itself, but also looking for possible legal and legitimate ways to overcome it (Aora, 2021).

In addition, in Paris, the publisher Etzel introduced Marco Vovchok to the French feminist writer Andre Leo (Leonie Chances), an active participant in the Paris Commune, who in her novels defended the equality of men and women.

The artistic and pedagogical interpretation of the problem of woman's emancipation was not a banal desire of Marko Vovchok to write on popular topics and thereby pave his way into big literature, her works boldly violated the taboo problems of the position of women in the Russian Empire, expanded ideas about ways to democratize society and ways to implement it programs for the emancipation of women in a totalitarian society.

Marco Vovchok builds his pedagogical concept of a self-sufficient woman not on the principles of Georges Sand, where men were the most passionate advocates of women's rights, but on the conviction of Charles Brontë embodied in the novel "Jane Eyre": the woman herself bears responsibility for her own destiny. The Ukrainian writer creatively developed the thoughts of the English author: her heroines, in the process of searching for ways of self-realization, take an active position in defending their own beliefs, fundamentally refusing any compromises (Bazhan, 2020; Brandis, 2002). 
The pedagogical essence of the "women's issue" Marko Vovchok actualized from the perspective of his own concept of personal and social freedom of a woman, responding to public discussions about her position (in the family, public life, the state), rights (in particular, knowledge about them and the ability to use), aspirations to like that. Since the end of the 50s. The writer herself paves the way for a rather difficult path for a free woman: after a divorce, despite the negative reaction of others, she actively communicates with men, boldly denying patriarchal views on the place of a divorced woman in society, realizing her own right to female happiness. Embodying the program of an independent independent life, the artist is engaged in creative and translation activities, gives her the opportunity to support herself and her son, even helps others to fulfill this dream: she creates an area where women have the opportunity to earn money, they are humiliated, such an active activity of Marko Vovchok, and not only " dissonant with the policy of the then government ", but at the same time" performed a difficult public function, was a protest not only against gender, but also against national discrimination. " (Broad, 2002)

For example, the writer, as a deep philosopher and psychologist, highlights the stages in the development of the heroine, in detail the spiritual evolution: from a persecuted child to a free personality. At the first stage, this is self-study, comprehension of nature, deep reflections and, as a result, denial and escape from the dirt and hypocrisy of her aunt's environment, so the girl was overwhelmed with "a thirst for life, activity, love - fresh, living love, and not dead, from everyone and everything that was torn away, colorless love. " The heroine's protest must first be an unconscious, spontaneous character, caused by the fear of becoming a resident of this dead kingdom. Living separately and providing herself financially, the heroine of the novel realizes the correctness of her choice, and the chosen one confirms her in this, who, despite repressions from the authorities and public condemnation, embodies her dream of living in the name of the people.

The author clearly recorded the psychological and pedagogical moment of Masha's transition to a higher stage of existence: old ideas were destroyed, but clear outlines of another life, another happiness were formed, "which she first of all depicted as vague, unclear, but bold and large features, now clearly and definitely", When" the last thin veil fell from her eyes, as if she had suddenly completely recovered and recovered, "when the girl clearly outlines the boundaries of her freedom, does not allow any person to cross, despite the reaction of others.

In the last part of the novel, the heroine appears as the author's ideal woman. Masha is a strong, uncompromising, decisive, purposeful, whole person, not afraid of difficulties, the dominant feature of her character is self-esteem: "I live, I live well, I am looking for and expect even better." The pinnacle of the heroine's evolution is the realization of the constant struggle for personal freedom, which is perceived as real happiness.

Traditionally, for works of this theme, the author presented a number of female types that are revealed in the search for personal happiness, but they are not found, following the traditional path. The writer, as an attentive psychologist and philosopher, shows the reasons for the failures of the heroines, challenges the social system and its hypocritical morality, which, based on the principles of a disdain for a person, leads to a tragedy of personality, distorting the idea of happiness. Agnes and Polinka are victims of distorted ideas about freedom and happiness. Both seek to get rid of unfreedom, but the laws and traditions of a totalitarian society make one suffer under the pressure of fear to violate the patriarchal canons, the other is made a freak, who, having lost her tyrant (mother), very quickly turns to him. "Slaves who were not freed themselves, and not by their own strength and struggle, but released by the generosity of their master or freed by the force of circumstances, always feel special pleasure when they can put a yoke on others," the writer concludes. Both heroines are not capable of deep feelings or an act to change their lives: Agnessa, blinded by the desire to escape from the pressure of her family, gives herself up to the first man she meets, in whom she very quickly becomes disappointed, and Polinka, in whom a cruel mother killed her ability to love, doomed to choose the idol of blind worship (Friedlander, 1971). 
The image of Masha simultaneously demonstrated the utopianism of the author's concept of a new type of woman, which manifests itself in modeling the character and character of the heroine. The scheme for the image of the new heroine, the author of "duty" in hagiographic literature, the traditions of which were very powerful in Ukrainian literature: a martyr's childhood, the desire to remain pure, the search for enlightenment. The main conflict is based on the dichotomy "body - spirit", "material - spiritual". Such antinomies and the motive of holiness emphasize the purity of Masha's thoughts, separate her from other heroines, and give her enlightenment. The spiritual core of the heroine's formation was the Gospel, which, in her opinion, was full of "ebullient earthly activity, passionate earthly concern for the earth." The writer leads the heroine through a series of trials, the most difficult of which is the trial of love: she is afraid to dissolve in falsehood, but concentrates and preserves herself for a spiritually close person. The heroine perceives her own life as service, asceticism. Her asceticism is a complete denial of the parasitic way of existence of the provincial nobility. Its goal is conscious and clearly motivated - the knowledge of the truth, and then the achievement of spiritual happiness and inner harmony (Krytikova, 1965).

A somewhat different pedagogical perspective on the implementation of the idea of a "new woman" will be presented by the novel Off the Beaten path, although the author constructs the heroine's story on the standard cliché for her works: the traumatic nature of childhood, alienation from the family, persistent desire to change her destiny. The main character Manya, the daughter of a serf and a depraved landowner, was brought up at the mercy of the landowner. She is observant, inquisitive, capable of critical thinking, educated, reads a lot. In contrast to Masha from the novel "Living Soul", first love brings dramatic changes to Manet's life. Having made a mistake in her feelings, she learns the true essence of society in its worst manifestations: immorality, inhumanity, indifference to the problems of another.

Alluring a very solid and strong nature: disappointed in the human qualities of his chosen one, he cuts off all ties with his previous life, starting from scratch. The image of Mani testifies to the active position of the author himself, who sought to create a type of effective woman adequate to modern social challenges. Manya does not live by dreams, she is capable of concrete actions in order to change the society in which she despaired. The author tests the populist ideology of small deeds in the novel. Therefore, Manya is a kind of experiment of the writer. In order to change social relations, the heroine does not refuse any work. The main principle of such a position of the heroine is disinterested assistance to everyone. Humanism, work, education are the leading factors that, combined with decisiveness, according to the heroine, can ensure changes in society. Such innovations of the writer in the interpretation of the "new woman" were rightly emphasized by V. Ageeva, comparing the image of Mani and Nora: an elegant porcelain figurine, but not enslave either. " (Lobach-Zhychenko, 1987)

The main feature of a new person, capable of influencing the world around her and changing it, is her desire, activity and decisiveness in this activity, the artist convinces with her novel. $\mathrm{N}$. Krutikova, comparing the images of Masha and Mani, rightly emphasized: "If the character of Masha in the novel" Living Soul "is shown by the author as already formed, then the character of Mani is demonstrated in development and formation. The girl goes through the path of spiritual and moral maturation. " Masha dreamed of ephemeral happiness for everyone, but Manya has a specific desire: to achieve justice and equality for all people. Masha lives with ideas, Manya lives with concrete, mundane deeds. "Through the thick of prejudices, through the fog of beautiful-hearted phrases, the girl Beckoning is making her way to the knowledge of the truth of life. On her own and others' mistakes, she learns to understand the true aspirations of the people around her. " ( $\mathrm{O}^{\prime}$ Neill, 2008)

The artistic progress in the implementation of the pedagogical concept of a new woman in this novel is amazing. If Masha ("Living Soul") sought to free herself from contradictory and 
deceptive social dogmas, to find her own happiness, then Mani's goal is much higher - to disinterestedly serve society for its happiness, even if for this it was necessary to sacrifice his life.

An integral part of Mark Vovchk's concept of a "new" woman is her sensuality. "Love is the highest force in the life of the heroines of Marko Vovchok," S. Pavlychko justly stated. All the heroines of the writer's works strive to find the harmony of existence, which is impossible without the realization of the right to personal happiness. However, only those women who are capable of strong and deep feelings reach it, can, like Manya ("In the wilderness") even die for them.

Philosophy problems of women have always been at the center of the writer's work. She actualized not only the question of a woman's ability for self-realization or the ability to take personal responsibility for her own life. The author put the question more broadly: her works and about the responsibility of society, tailored according to masculine patterns, for the fate of a woman.

The author also presented the feeling of a woman's awakening, her aspirations to be free, the ability for self-realization in the works, the main character of which is a woman from the people. A new stage in the formation of a new image of a woman is the essays "Rural idyll" and "Journey into the interior of the country."

In the essay "Rural idyll" by Marko Vovchok, the emphasis on the peculiarities of the spiritual world of a woman, from the people, aspires from the elephant her "simple, but full of freshness and poetry of the inner world." As in his early works, Marko Vovchok turned to the image of a woman, who is at the lowest social level in the social hierarchy. However, now the author's goal is to draw attention to the problem of blocking the possibilities of a woman's personal and social selfrealization. The writer saw the reasons for this phenomenon not only in the social plane, but also in the traditional patriarchal bias in relation to the educational and spiritual needs of women (Pavlychko, 2002; Smith, 2002; Marko, 1967; Waithe, 1987).

The work is built in the form of a monologue-confession of a reaper, who tells the story of her life. As a skilled psychologist, the writer builds the tragedies of unrealized individuals, fixes the neglected traumas of a person deprived of the right to education, self-development, socially useful work. Childhood dreams of an elated life destroys her slave position in the family: in childhood in the parental family, after marriage - in her husband's. Hard, hopeless work, social lawlessness destroy aspirations, kill faith, turn a hardworking, inspired, sensual person into a machine for exploitation. For the first time in national literature, Marko Vovchok turned to feminist issues, contrasting the female and male worlds, because while the reaper is working hard, her relative grandfather, who has learned to read, has the opportunity to discover the world for himself, because the attitude of society towards men and women is different. To the reproach of the narrator that the grandfather reads all day, the heroine bitterly replies: "And who feeds him?" The title of the work sounds more than ironic: a rural idyll is a world of inequality of members of a rural community, the sphere of responsibility of a woman in which family life and raising children is extremely narrowed.

The essay "A Journey Into the Country" is interesting in that the writer closely connected the problems of a moral and ethical character traditional for the great prose of Mark Vovchka with social and national ones.

In the work of Marko Vovchok, for the first time he actualizes gender issues, clearly outlining the feminine and masculine, their natural, psychological and ideological principles. The plot is based on the opposition of the mental characteristics of the Ukrainian girl and the Russian men captured by her beauty, emphasizes the difference between the two ethnic groups.

The philosophy of men in the work is represented by representatives of different social strata: nobility, merchants, nobility, townspeople, students, whom the author unites by nationality. They are opposed by the main character, a Ukrainian girl. The reader recognizes a Ukrainian woman in her through her language, appearance, details of clothing, and most importantly, her traditional 
mentality. "The luxurious child of Ukraine", the "black-eyed girl", is the only female representative, boldly fends off all the advances and reproaches of men, is not inferior in intelligence, ingenuity, desire to know the world around her, and surpasses her counterparts in sensitivity, sincerity and moral qualities (Olympia, 2011).

The border between the female and male world runs along the line of a sensual and pragmatic attitude to the problems of life, where, on the one hand, humanity, mercy, compassion, openness to the world, and on the other, indifference, cruelty, callousness. Men who love female beauty, who are not able to hear or understand a woman, and her calls not to spend money on whims and courtship, but to help the hungry, are perceived with laughter. The writer boldly proves that men are accustomed to perceiving a woman only as a toy or a servant, therefore her desire to gain knowledge for free existence causes a range of negative male emotions: from misunderstanding to indignation and skepticism. However, the writer states, times have changed. A woman confidently fights for her rights, and most importantly, the right to education, which guarantees the possibility of an independent life and earnings. It is not worth the Ukrainian woman seeks to reach out to the not always rational, often spiritually unspiritual, immoral Russian world a cardinal mental difference in the views of not only two articles, but two nations will always separate them.

\section{CONCLUSION}

Throughout history, the role of women in society has changed. In modern society, women are still discriminated against on the basis of gender. Equality of human rights for women compared to men is advocated by the feminist movement. The democratization and humanization of modern Ukrainian society presupposes the orientation of our state to the establishment of common universal principles and standards, to their natural principles, which are important for the entire world community. One of the most important universal principles is the principle of equality - the recognition that all people should be equal to each other, regardless of any particularities. In recent years, the issue of gender equality has become increasingly important in all spheres of human life. The world process of formation of constitutional legislation is characterized by the declaration of the principle of equal rights and opportunities. The constitutional enshrinement of gender equality is characterized by such features as national and racial independence, language, religion, social origin, political beliefs and more.

Modern women's prose is actively rethinking the historical past of Ukraine. The female gaze offers an alternative story where the man is at the center. The works emphasize the problems of gender-based violence, the source of which is not so much an attempt to seize the female body as a demonstration of strength to a political opponent. The writers show that the heroines are only hostages in the struggle for power in the male world, violence destroys women as full-fledged individuals, depriving them of traditional role identifications.

Marko Vovchok is a philosopher and innovative writer. She was the first among writers to speak openly and loudly about the problems of women and her rights. The Russian-language prose of the writer is imbued with modern trends in world literature in creating the image of a "new woman". The basis of most of the writer's works is the idea of freeing women from economic, moral and spiritual dependence, realized through a conscious desire to uphold social equality with men. Her heroine is capable not only of impulses, courageously breaking with her environment, she has her own program of life, in the process of implementation of which she endures trials, sacrificing everything except her own principles and dignity, embodying a specific goal: to be a free, independent person.

Marko Vovchok solved the "women's issue" in terms of gender issues. The writer explained the social position of a woman, her powerlessness by the dominance of the male world, because in 
a patriarchal society, where an exclusively masculine outlook on life reigns, the feminine personality is deprived of the possibility of self-realization, the free choice of one's own life path.

Marko Vovchok opened the door for further pedagogical evolution of a whole range of topics: woman's upholding of a worthy place in society, reflection of the uniqueness of the feminine world, active opposition to patriarchal traditions in everyday life and social life, etc., which found their continuation in the works of $\mathrm{O}$. Kobylianska, Lesya Ukrainsky, N. Kobrinskaya, V. Kravchenko and other writers who actively defended the rights of women in the social, economic and political spheres of life.

Authors' Contributions: Lipnytska, I.: conception and design, acquisition of data, analysis and interpretation of data, drafting the article, critical review of important intellectual content; Savchenko, I.: conception and design, acquisition of data, analysis and interpretation of data, drafting the article, critical review of important intellectual content; Halak, I.: conception and design, acquisition of data, analysis and interpretation of data, drafting the article, critical review of important intellectual content; Hryhorenko, I.: conception and design, acquisition of data, analysis and interpretation of data, drafting the article, critical review of important intellectual content; Bykova, T.: conception and design, acquisition of data, analysis and interpretation of data, drafting the article, critical review of important intellectual content. All authors have read and approved the final version of the manuscript.

Ethics Approval: Not applicable.

Acknowledgments: Not applicable.

\section{REFERENCES}

Ageeva V, (2002) Male pseudonym and female independence (an attempt by gynecritics) Three destinies of Marko Vovchok in Ukrainian, Russian and French literature: anthology / comp. V. Ageeva. Kiev: Fact, 103-113.

Ageeva V. (2019) emancipated. Marko Vovchok. Emancipated: Stories and Novels. Kiev: Publishing House "Komora", $5-26$.

Arora, S. (2021), "PRISM philosophy: empowering women in COVID times!", The Case For Women. https://doi.org/10.1108/CFW.2020.000014

Bazhan A. (2020) "Luxintenebris" through the prism of gender studies (based on the prose of Marko Vovchok and Hanna Barvinok. http://dspace.nuft.edu.ua/jspui/bitstream/123456789/21746/1/1.pdf

Brandis E. (2002) Marko Vovchok / trans. from rus. Kiev: Dnipro. 368 p.

Broad, J. (2002), Women Philosophers of the Seventeenth Century. Cambridge.

Friedländer G. (1971) At the origins of the "pochvennichestvo" (F. M. Dostoevsky and the journal "Svetoch"). Izv. Academy of Sciences of the USSR. Ser. lit-ry and language. No. 5. P. 405.

Krutikova N. (1965) Pages of creative life (Marko Vovchok in life and work). Kiev: Dnepr, 389 p.

Lobach-Zhuchenko B. (1987) In Marko Vovchok: memories, searches, finds .. Kiev: Dnipro, 399 p.

O’Neill, E. (2008), 'Disappearing Ink: Early Modern Women Philosophers and their Fate in History', in Philosophy in a Feminist Voice: Critiques and Reconstructions, ed. Janet A. Kourany pp. 17-62.

Olympia de Gouge. (2011) Declaration of the rights of women and citizens. http://ravnopravka.ru/2011/03/olimpiade-guzh-declaration-women-rights/

Pavlychko S. (2002) Feminism Kiev: Publishing house of Solomiya Pavlychko "Foundations", 322 p.

Smith, L., (1998) Women Writers and the Early Modern British Political Tradition. Cambridge.

Top Marko. (1967) Works. In 7 volumes, Kiev: Naukova Dumka, V.3. 669 p.

Waithe, M. (1987), A History of Women Philosophers, 4 vols. Dordrecht, London, and Boston, 87-95.

Received: 2 July 2021 | Accepted: 5 September 2021 | Published: 30 September 2021 